\title{
Bagaimana Pengasuhan Spiritual Mampu Membangun Karakter yang Baik pada Remaja Muslim?
}

\author{
Yuliana Intan Lestari \\ Fakultas Psikologi Universitas Islam Negeri Sultan Syarif Kasim Riau \\ email: anayuliana.psikologi@uin-suska.ac.id
}

\section{Artikel INFO}

Diterima:30 Sept 2019

Direvisi : 17 Okt 2019

Disetujui: 04 Des 2019

DOI:

http://dx.doi.org/10.24014/ jp.v14i2.7794

\begin{abstract}
Abstrak
Membangun karakter yang baik adalah upaya yang penting bagi diri remaja,khususnya remaja muslim dengan latar belakang nilai-nilai yang dianutnya. Namun hal tersebut tidaklah mudah tanpa peran dari pengasuhan yang diberikan orangtua di dalam keluarga. Penelitian ini bertujuan untuk melihat bagaimana pengasuhan spiritual dalam keluarga mampu membangun karakter yang baik pada remaja muslim. Partisipan dalam penelitian ini berjumlah 200 orang. Data penelitian diperoleh dengan menggunakan skala psikologis yakni skala spiritual parenting dan skala good character. Analisa data yang digunakan menggunakan teknik korelasi product moment. Hasil analisis menunjukkan adanya hubungan yang signifikan antara pengasuhan spiritual dengan karakter yang baik pada remaja muslim dengan $r$ korelasi bernilai $0,412(p=0.000)$. Artinya semakin baik pola pengasuhan spiritual maka semakin baik karakter yang terbentuk pada diri mereka. Hal tersebut menggambarkan bahwa keberhasilan dalam membangun pondasi yang kokoh dalam pembentukan karakter yang baik pada remaja tidak lepas dari peran penting orangtua dalam memberikan pola pengasuhan spiritual pada remajanya.
\end{abstract}

Kata kunci: pengasuhan spiritual, karakter, nilai

\section{How the Spiritual Parenting Can Build Good Character for Moeslim Adolescence?}

\begin{abstract}
Building good character is an important effort for adolescents, especially Muslim adolescents with a background in their values. But this is not easy without the role of care given by parents in the family. This study aims to examine how spiritual parenting in the family is able to build good character in Muslim adolescents. Participants in this study was 200 people. The research data was obtained using psychological scales, namely the spiritual parenting scale and the good character scale. Data of this study was analysed by using product moment correlation technique. The results of the analysis showed a significant relationship between spiritual parenting and good character in Muslim adolescents with $(r)$ correlation $=0.412(p=0.000)$. Its means that the increasing of the spiritual parenting can make a good character in them. This illustrates that success in building a solid foundation in the formation of good character in adolescents can not be separated from the important role of parents in providing patterns of spiritual parenting in adolescents.
\end{abstract}

Key words: spiritual parenting, character, value

\section{Pendahuluan}

Kehidupan remaja yang penuh dengan kompleksitas permasalahan sosial yang muncul menyebabkan terjadi perubahan karakter kearah yang tidak sesuai dengan harapan sosial. Seringkali remaja hanya dipenuhi kebutuhan jasmaninya (makan, pakaian, mainan, tempat tinggal, biaya sekolah) tapi melupakan kebutuhan ruhaninya (kasih sayang, belaian, canda tawa, dialog dari hati, khususnya ilmu spiritual) sehingga mereka tumbuh menjadi remaja-remaja yang kering dan hampa. Generasi seperti ini tentunya sulit diharapkan untuk menjadi pencerah peradaban, karena mereka hanya kuat di "fisik" namun sangat rapuh "ruh"nya. (Hairina, 2016).

Masa remaja ditandai dengan periode peralihan dari masa anak-anak ke masa dewasa. Peralihan remaja tidak lagi dikatakan ana-anak tetapi juga belum sepenuhnya menjadi individu dewasa. Masa remaja merupakan masa dimana seorang individu 
mengalami perubahan baik emosi, tubuh, minat, pola perilaku, dan juga penuh dengan masalah-masalah sosial. Perubahanperubahan ini adalah dinamika kehidupan yang kompleks sehingga sulit dilewati individu remaja. Oleh karenanya, remaja sangat rentan sekali mengalami masalah psikososial, yakni masalah psikis atau kejiwaan yang timbul sebagai akibat terjadinya perubahan sosial (Hurlock, 1998).

Clinebell (dalam Suhariyanto, 2011) menegaskan bahwa remaja memiliki kebutuhan dasar spiritual yang harus dipenuhi agar dapat membawa remaja dalam keadaan yang tentram, aman, damai dalam menjalani hidup. Jika kebutuhan tersebut tidak dipenuhi, maka dapat menyebabkan kecemasan neurotis dan kekosongan spiritual dalam diri remaja. Kekosongan spiritual (spiritual-emptiness) akan menyebabkan penyakit ketidakbermaknaan spiritual (spiritual-meaningless). Dalam kondisi yang demikian, remaja akan mudah terpengaruh dan terombang-ambing oleh pengaruh lingkungan sekitarnya yang memunculkan prilaku yang tidak bermoral karena remaja tidak punya benteng yang cukup, kehilangan pegangan hidup, kehilangan keimanan dan mudah untuk putus asa (hopeless).

Prilaku yang tidak bermoral yang ada pada remaja mengindikasikan remaja belum memiliki karakter yang baik. Karakter (character) mengacu pada serangkaian sikap (attitudes), perilaku (behaviors), motivasi (motivations) dan keterampilan (skilss). Menurut Musfiroh (2008) karakter meliputi sikap seperti keinginan untuk melakukan hal yang terbaik, kapasitas intelektual seperti berfikir kritis dan alasan moral, perilaku seperti berkata jujur dan bertanggungjawab, mempertahankan prinsip-prinsip moral dalam situasi penuh ketidakadilan, kecakapan interpersonal dan emosional yang memungkinkan seseorang berinteraksi secara efektif dalam berbagai keadaan dan komitmen untuk berkontribusi dengan komunitas dan masyarakatnya. Karakter adalah realisasi perkembangan positif sebagai individu (intelektual, sosial, emosional dan etika). Individu yang berkarakter baik adalah seseorang yang berusaha melakukan hal yang terbaik.

Namun, proses pengasuhan orangtua tidak selalu sesuai dengan yang diharapkan dantidaklah sesederhanayang kita bayangkan dan katakan. Pada kenyataannya pada kondisi sekarang ini masih banyak orang tua yang kurang menyadari apa penyebab dari tingkah laku anak mereka. Orang tua lebih melempar tanggungjawab pembinaan anak sepenuhnya kepada pihak sekolah. Padahal penanaman karakter pada diri anak bukan hanya tanggung jawab guru di sekolah, artinya tidak harus melalui jalur pendidikan formal.

Pada era globalisasi saat ini merupakan tantangan besar bagi para orangtua untuk mendidik dan mengasuh anak. Teknologi yang semakin canggih dan akses informasi yang semakin mudah sedikit banyak mempengaruhi perkembangan jiwa anak. Berbagai fasilitas modern diberikan pada anak seperti kebebasan menggunakan gadget, handphone, game inline, akses internet yang bebas. Hal ini memberikan ruang kebebasan yang cukup besar bagi diri remaja untuk melakukan berbagai hal yang disenanginya. Akibatnya, fenomena di masyarakat kita saat ini terhiasi dengan kian maraknya tawuran antar pelajar, geng motor, perilaku remaja yang menyimpang, seks bebas, pornografi, bullying dan masih banyak kasus-kasus lainnya. Perilaku-perilaku anak seperti yang diuraikan di atas tidak serta merta terjadi begitu saja, melainkan melalui suatu proses pembelajaran dengan kondisi dan situasi yang terjadi di sekitar kehidupannya. Anak dengan segala perilakunya, membawa suatu model dan bentuk karakter dalam dirinya, yang diperoleh dari atau dibentuk oleh lingkup kehidupannya, terutama dari orangtua.

Pada akhirnya orang tua juga yang banyak mengeluh atas kenakalan anak-anak mereka yang sukar dikendalikan, keras kepala, tidak mau menurut perintah orang tua, sering berkelahi, tidak mau belajar, merusak milik orang lain, merampok, menipu dan suka berbohong serta kerendahan moral lainnya. Kasus- kasus itu antara lain disebabkan ketidaktahuan orang tua akan pentingnya mengasuh dan mendidik anak dengan baik, ini menjadikan anak sebagai korban, orang tua selalu menyalahkan anak, tanpa mereka sadari bahwa apa yang sekarang menjadi kepribadian anak adalah hasil dari pola asuh yang orang tua terapkan pada anak, orang tua mungkin cenderung bersikap kasar, otoriter, acuh tak acuh, atau terlalu memanjakan anak, sehingga anak tumbuh menjadi sosok yang egois, agresif, dan kesulitan dalam bersosialisasi, dan lainlainnya. Jika kondisi ini dibiarkan, kasuskasus seperti ini nampaknya akan terus 
meluas seiring perkembangan kemajuan zaman. Dan jika hal ini terus berlanjut maka anak sebagai generasi masa depan tidak mempunyai dasar karakter yang kuat dalam menghadapi tantangan zaman.

Oleh karena itu pembentukan karakter sangat diperlukan khususnya bagi remaja. Secara umum, pembentukan karakter sebagai upaya yang dengan sadar dirancang untuk membantu individu mengembangkan pengetahuan, keterampilan, dan kepribadiannya (Widajat, 2011). Selanjutnya Sudrajat (2010) menyatakan bahwa pendidikan pembentukan karakter adalah sistem penanaman nilai-nilai karakter kepada remaja yang meliputi komponen pengetahuan, kesadaran atau kemauan, dan tindakan untuk melakukan nilai-nilai tersebut, baik kepada Tuhan Yang Maha Esa, diri sendiri, sesama, lingkungan, maupun kebangsaan sehingga menjadi manusia insan kamil. Lickona (1992) menekankan pentingnya tiga komponen karakter yang baik (component of good character) yaitu moral knowing atau pengetahuan tentang moral, moral feeling atau perasaan tentang moral dan moral action atau perbuatan moral. Hal ini diperlukan agar remaja mampu memahami, merasakan dan mengerjakan sekaligus nilai-nilai kebajikan.

Keluarga merupakan lembaga pedidikan dasar bagi remaja yang memiliki peran sentral dan strategis dalam meletakkan dasar-dasar keberagamaan bagi remaja. Jalaluddin (2010) menambahkan bahwa suatu pola pengasuhan keluarga yang menekankan pentingnya penerapan gaya pengasuhan yang bernilai agama kepada remaja dapat mengembangkan prilaku bermoral dan potensi mereka sebagai makhluk beragama. Mendidik remaja merupakan bagian terpenting dari orangtua agar dapat membentuk remaja sesuai harapan. Pola asuh yang diterapkan sangat berpengaruh dalam membentuk karakter remaja. Keluarga adalah lembaga pendidikan pertama yang mempunyai peranan penting dalam membentuk karakter dan watak remaja (Ajisuksmo, 2010). Keluarga mempunyai peranan penting dalam membentuk jati diri dan pembentukan karakter remaja. Karakter bukan sekedar hasil dari sebuah tindakan melainkan secara simultan merupakan hasil dan proses (Santrock, 2008). Karakter erat kaitannya dengan personality (kepribadian) seseorang, dimana seseorang dapat disebut orang yang berkarakter (a person of character) jika tingkah lakunya sesuai dengan kaidah moral. Keluarga mempunyai peranan dalam membentuk alam spiritual dan moral remaja.

Nashori (2006) menyatakan dalam khazanah pemikiran psikologi kontemporer, gagasan tentang peran orangtua dalam meningkatkan spiritualitas termasuk konsep Tuhan pada diri anak diwadahi oleh konsep spiritual parenting. Pamugari (dalam Irianto, 2002) mendefenisikan spiritual parenting sebagai sistem pengasuhan anak dengan paradigma menanamkan keimanan dan kesadaran rohani. Sementara menjadi orang tua dengan menerapkan spiritual parenting berarti memprioritaskan kehidupan diri kita sendiri, dimana Tuhan berada pada urutan tertinggi, sehingga jiwa orangtua dan jiwa anak menjadi sangat penting. Spiritual parenting mengimplikasikan bahwasanya orang tua tidak hanya hadir untuk anak mereka, namun juga untuk diri mereka sendiri (Hart, 2004). Seseorang yang lebih dulu mengakui diri sendiri sebagai makhluk spiritual, maka seseorang itu dapat mendidik anak-anak dengan menyadari bahwa anak-anak adalah individu yang benar-benar berketuhanan (Doe, 1998).

Sebuah hadist menegaskan bahwa tugas utama kerasulan Muhammad SAW adalah untuk menyempurnakan akhlak (karakter). Ini berarti telah ada benih akhlak pada masing-masing manusia, tinggal bagaimana lingkungan pendidikan dapat mengoptimalkan benih-benih tersebut. Sebagaimana sabda Rasulullah SAW yang artinya, "Sesungguhnya aku diutus ke muka bumi ini adalah untuk menyempurnakan akhlak manusia". (HR. Ahmad, Baihaqi, dan Malik).

Hidayat (dalam Irianto, 2002) menambahkan bahwa prinsip spiritual parenting bisa diterapkan misalnya dengan mengajak anak untuk mengapresiasi Tuhan melalui ciptaannya, bisa melalui keindahan alam, sinar matahari, ataupun warna-warni bunga, anak diajak mengagumi dan menghayati karya Tuhan. Doe (dalam Irianto, 2002) lewat bukunya juga mengutarakan cara mengimplementasi prinsip spiritual parenting, inti penerapannya tidak jauh berbeda dengan pendidikan agama yang diterapkan selama ini. Bedanya, metode baru ini tidak mencekoki anak dengan doktrin-doktrin ketuhanan. la merangsang anak untuk berpikir tentang Tuhan, memberikan pencitraan Tuhan yang mencintai, bukan Tuhan yang menunggu dengan rotan untuk memukul. 
Pola pengasuhan remaja dalam spiritual parenting membantu menyadarkan remaja sedini mungkin bahwa mereka adalah ciptaan Tuhan dan mempunyai kewajiban untuk beribadah kepada Nya. Pola pengasuhan ini sangat mudah untuk diterapkan karena konsep spiritualitas hadir selalu dalam kehidupan kita sehari-hari, misalnya dalam percakapan orangtua dengan remaja, menyelesaikan tugas sehari-hari, mendongeng sebelum tidur dan sebagainya. Spiritual parenting merangsang remaja untuk berpikir tentang Tuhan sehingga remaja mampu mengendalikan diri dari pengaruh buruk lingkungan karena tidak sesuai dengan apa yang diajarkan kepada mereka. Jika remaja-remaja merasakan kehadiran Tuhan dalam setiap aspek kehidupan, mereka akan berkembang menjadi remaja yang taat beribadah. Remaja akan menyadari bahwa beribadah dalam kehidupan sama halnya beribadah dalam agama. (Hany, 2013.,Bert, 2011.,Callaghan, 2005.,Zohar \& Marshall, 2001)

Pendidikan karakter merupakan misi utama para rasul diutus Allah di muka bumi. Dan Islam hadir sebagai gerakan untuk menyempurnakan karakter. Islam menegaskan bahwa pendidikan yang baik adalah hak anak atas orang tua dan pendidikan yang baik yang dimaksud Islam adalah pendidikan yang sesuai dengan tuntunan al-Qur"an dan tujuan-tujuannya dalam membentuk kepribadian muslim yang berserah diri secara total kepada Tuhannya dengan tuntunan yang telah diajarkan oleh Rasulullah saw.

Inti dari spiritual parenting adalah usaha yang dapat ditempuh orang tua dalam kehidupan sehari-hari untuk menguatkan spiritualitas anak. Gagasan umumnya adalah mengakrabkan konsep Tuhan kepada anak-anak sejak usia dini (Nashori, 2006). Berdasarkan uraian di atas maka pengertian spiritual parenting adalah pola asuh menempatkan Tuhan pada urutan tertinggi, dalam sikap dan perilaku, yang diterapkan oleh orang tua dalam berinteraksi dengan anak, meliputi cara orang tua memberikan aturan-aturan, atau hukuman, dan cara orangtua memberikan perhatian serta tanggapan terhadap anaknya. Menurut Nashori (2006) komponen dari spiritual parenting meliputi pola asuh menempatkan Tuhan pada urutan tertinggi, dalam sikap dan perilaku, yang diterapkan oleh orang tua dalam berinteraksi dengan anak, meliputi cara orang tua memberikan aturan-aturan, atau hukuman, dan cara orangtua memberikan perhatian serta tanggapan terhadap anaknya.

Perhatian dan pemahaman keluarga memasukkan nilai-nilai agama dalam pola pengasuhannya dalam rangka membentuk peran positif remaja dimasa yang akan datang akan menjadi motivasi utama untuk perkembangan remaja. Pola pengasuhan seperti inilah yang dikenal dengan spiritual parenting atau pola pengasuhan spiritual. Spiritual parenting adalah pola asuh menempatkan Tuhan pada urutan tertinggi, dalam sikap dan perilaku, yang diterapkan oleh orang tua dalam berinteraksi dengan anak, meliputi cara orang tua memberikan aturanaturan, atau hukuman, dan cara orangtua memberikan perhatian serta tanggapan terhadap anaknya (Irianto, 2002). Pamugari (dalam Irianto, 2002) mendefenisikan spiritual parenting sebagai sistem pengasuhan anak dengan paradigma menanamkan keimanan dan kesadaran rohani.

Berdasarkan uraian di atas, penulis merasa penting untuk melakukan kajian penelitian ini yang dapat memberi kontribusi bagi pengembangan ilmu pengetahuan khususnya bidang ilmu psikologi yang fokus mengkaji permasalahan remaja dengan berbagai problemanya. Oleh karena itu penulis merasa perlu kiranya untuk melakukan telaah lebih lanjut tentang bagaimana pengasuhan spiritual mampu membangun karakter yang baik pada remaja muslim?.

\section{Karakter yang Baik}

Istilah karakter jika dikaitkan dengan masalah kejiwaan manusia merupakan bagian yang sangat penting. Jika didalam diri manusia tidak ditemukan karakter yang melekat, maka manusia kehilangan jati dirinya sebagai makhluk yang mulia. Dalam kamus besar Bahasa Indonesia karakter didefinisikan sebagai sifat-sifat kejiwaan atau budi pekerti yang menjadi ciri khas seseorang. Menurut Hernowo, karakter adalah watak, sifat atau hal-hal yang memang sangat mendasar yang ada pada diri seseorang sebagai tabiat dan akhlak atau budi pekerti yang membedakan seseorang dengan yang lain yang terefleksi dari perilakunya sehari-hari. Pengertian karakter diatas tampaknya sama dengan pengertian akhlak dalam pandangan Islam. Menurut pandangan Islam, akhlak adalah sifat yang berada dalam jiwa yang mendorong seseorang untuk melakukan perbuatan 
secara natural dan refleks tanpa memerlukan pemikiran dan pertimbangan. Perbuatan seseorang akan menjadi karakter atau akhlak apabila dilakukan secara berulang-ulang dan menjadi kebiasaan (Matta, 2006).

Dalam konteks pembentukan karakter individu, partisipasi orang tua mutlak diperlukan mengingat harus ada pembiasaan yang kontiniu dari individu dalam berprilaku baik di rumah maupun di sekolah. Disamping ada pembiasaan yang baik, juga harus ada pemantauan yang cermat atas prilaku-prilaku yang dilakukan individu sehingga proses pembentukan karakter individu kearah yang lebih baik dan menjadi pribadi yang berkarakter dapat tercapai.

\section{Aspek Pembentuk Karakter}

Membentuk karakter anak diperlukan syarat-syarat mendasar bagi terbentuknya kepribadian yang baik. Menurut Megawangi (2003) ada tiga kebutuhan dasar anak yang harus dipenuhi, yaitu maternal bonding, rasa aman, dan stimulasi fisik dan mental. Maternal bonding (kelekatan psikologis dengan ibunya) merupakan dasar penting dalam pembentukan karakter anak karena aspek ini berperan dalam pembentukan dasar kepercayaan kepada orang lain (trust) pada anak. Kelekatan ini membuat anak merasa diperhatikan dan menumbuhkan rasa aman sehingga menumbuhkan rasa percaya. Menurut Erikson dasar kepercayaan yang ditumbuhkan melalui hubungan ibuanak pada tahun-tahun pertama kehidupan anak akan memberi bekal bagi kesuksesan anak dalam kehidupan sosialnya ketika ia dewasa. Dengan kata lain, ikatan emosional yang erat antara ibu-anak di usia awal dapat membentuk kepribadian yang baik pada anak.(Papalia, 2005)

Sudah diketahui orang banyak, ada tiga ranah besar yang menjadi garapan dalam ilmu psikologi, yaitu : kognisi, afeksi dan psikomotor. Terkait dengan bahasan karakter, ketiga ranah tersebut dijabarkan menjadi: a. Knowledge dengan mengembangkan proses berfikirnya (Thinking), b. Attitude dengan mengembangkan bagaimana mengelola perasaan (Feeling), dan c. Skill dengan mengembangkan bagaimana individu bertindah (Doing). Aspek-aspek karakter tersebut tidak akan berkembang dengan sendirinya secara liar, tetapi anak membutuhkan bimbingan, panduan dan keteladanan dari orangtua dan orang-orang dewasa lain di sekitar kehidupannya. Aspekaspek karakter akan berkembang melalui proses: melihat, meniru dan kemudian akan disimpan atau dibuang oleh individu tergantung pada kebutuhannya saat itu. UNESCO menerjemahkan pembentukan karakter melalui aspek-aspek : learning to know, learning to do, learning to be dan learning to live together.(Karsidi, 2010)

Berdasarkan beberapa uraian diatas dapat disimpulkan bahwa karakter atau akhlak adalah bentuk kepribadian seseorang yang dapat dilihat dalam tindakan nyata yang berupa tingkah laku seperti jujur, bertanggungjawab, kerja keras, menghormati dan lainnya. Menurut Madjid (2000), komponen dalam good character (karakter yang baik) individu dapat dikelompokkan menjadi 3 macam yaitu: Karakter yang berkaitan dengan nilainilai ke-Tuhanan (Ilahiyah) seperti iman, islam, ikhsan, tawakkal, syukur dan sabar. Karakter yang berkaitan dengan nilai-nilai kemanusiaan secara universal (Insaniyah), yang diwujudkan dalam bentuk prilaku seharihari seperti silaturrahmi, persaudaraan, keadilan, toleransi, rendah hati, tepat janji, dermawan, kepemimpinan, dapat dipercaya dan kedamaian. Karakter yang berkaitan dengan nilai-nilai kemanusiaan sebagai makhluk individu seperti kerja keras, integritas, sikap positif, kontrol diri, kejujuran, kesederhanaan, kreatif, tanggung jawab, disiplin, hemat dan mandiri.

\section{Proses Pembentukan Karakter}

Karakter, seperti juga kualitas diri yang lainnya, tidak berkembang dengan sendirinya. Perkembangan karakter pada setiap individu dipengaruhi oleh faktor bawaan (nature) dan faktor lingkungan (nurture). Menurut para developmental psychologist, setiap manusia memiliki potensi bawaan yang akan termanisfestasi setelah dia dilahirkan, termasuk potensi yang terkait dengan karakter atau nilai-nilai kebajikan. Dalam teori psikologi, pembentukan karakter anak dimulai dari usia 0-8 tahun. Artinya dimasa usia tersebut karakter anak masih dapat berubahubah tergantung dari pengalaman hidupnya. Oleh karena itu, membentuk karakter harus dimulai sedini mungkin bahkan sejak anak itu dilahirkan, karena berbagai pengalaman yang dilalui oleh anak semenjak perkembangan pertamanya, mempunyai pengaruh yang besar dalam mewujudkan pembentukan karakter secara utuh. 
Pengembangan karakter seseorangan pada usia emas (golden age), terbukti sangat menentukan kemampuan anak dalam mengembangkan potensinya. Hasil penelitian menunjukkan bahwa sekitar $50 \%$ variabilitas kecerdasan orang dewasa sudah terjadi ketika berada pada usia 4 tahun. Peningkatan $30 \%$ berikutnya terjadi pada usia 8 tahun, dan $20 \%$ sisanya pada pertengahan atau akhir dasawarsa kedua. Oleh karenanya sudah sepatutnya pengembangan karakter dimulai dari dalam keluarga yang merupakan lingkungan pertama bagi pertumbuhan karakter anak. Karakter yang kuat dibentuk oleh penanaman nilai-nilai yang menekankan tentang baik dan buruk. Nilai ini dibangun melalui penghayatan dan pengalaman, meningkatkan rasa ingin yang sangat kuat, serta bukan hanya menyibukkan diri dengan pengetahuan. Oleh karena itu, jika sejak kecil sudah dibiasakan mengenal karakter positif, maka anak akan tumbuh menjadi pribadi yang tangguh, percaya diri dan empati, sehingga anak tersebut akan kehilangan jika tidak melakukan kebiasaan baiknya.

Dalam hal ini Erikson menyebutkan bahwa anak adalah gambaran awal manusia menjadi manusia, yaitu masa di mana kebajikan berkembang secara perlahan tapi pasti, dengan kata lain, bila dasar-dasar kebajikan gagal ditanamkan pada anak di usia dini, maka dia akan menjadi orang dewasa yang tidak memiliki nilai-nilai kebajikan.

\section{Spiritual Parenting}

Spiritualitas menurut Schreurs (2002) merupakan hubungan personal seseorang terhadap sosok transenden. Spiritualitas mencakup inner life individu, idealisme, sikap, pemikiran, perasaan dan pengharapannya terhadap Yang Mutlak. Spiritualitas juga mencakup bagaimana individu mengekspresikan hubungannya dengan sosok transenden tersebut dalam kehidupan sehari-harinya.

Elkins (1988) merujuk spiritualitas sebagai cara individu memahami keberadaan maupun pengalaman yang terjadi pada dirinya. Bagaimana individu memahami keberadaan maupun pengalamannya dimulai dari kesadarannya mengenai adanya realitas transenden (berupa kepercayaan kepada Tuhan atau apapun yang dipersepsikan individu sebagai sosok transenden) dalam kehidupan dan dicirikan oleh pandangan atau nilai-nilai yang dipegangnya berkaitan dengan diri sendiri, orang lain secara universal, alam, hidup, dan apapun yang dipersepsikannya sebagai Yang Mutlak.

Maslow mendefinisikan spiritualitas sebagai sebuah tahapan aktualisasi diri seseorang, di mana seseorang berlimpah dengan kreativitas, intuisi, keceriaan, sukacita, kasih, kedamaian, toleransi, kerendahhatian, serta memiliki tujuan hidup yang jelas. Menurut Maslow, pengalaman spiritual adalah puncak tertinggi yang dapat dicapai oleh manusia serta merupakan peneguhan dari keberadaannya sebagai makhluk spiritual. Pengalaman spiritual merupakan kebutuhan tertinggi manusia. Bahkan Maslow menyatakan bahwa pengalaman spiritual telah melewati hierarki kebutuhan manusia.

Berdasarkan berbagai defenisi dari penjelasan di atas, peneliti berkesimpulan bahwa spiritualitas adalah kesadaran manusia akan adanya keterhubungan antara manusia dengan Tuhan atau sesuatu yang dipersepsikan sebagai sosok transenden. Spiritualitas mancakup inner life individu, idealisme, sikap, pemikiran, perasaan dan pengharapannya terhadap Yang Mutlak. Spiritualitas juga mencakup bagaimana individu mengekspresikan hubungannya dengan sosok transenden tersebut dalam kehidupan sehari-harinya.

Menurut Darling (1999) pola asuh (parenting) adalah suatu aktifitas yang kompleks yang meliputi beberapa tingkah laku spesifik yang bekerja secara sendirisendiri maupun bersama-sama untuk mempengaruhi anak. Pengertian parenting menurut Gunarsa (1995) adalah cara orang tua bertindak sebagai orang tua terhadap anak-anaknya dimana mereka melakukan serangkaian usaha aktif. Parenting adalah perlakuan orang tua dalam rangka memenuhi kebutuhan, memberi perlindungan dan mendidik anak dalam kehidupan sehari-hari (Meichati, 1978). Menurut Gunarsa (1989) keluarga merupakan lingkungan kehidupan yang dikenal anak untuk pertama kalinya, dan untuk seterusnya anak belajar didalam kehidupan keluarga.

Berdasarkan uraian diatas maka dapat disimpulkan bahwa pola asuh adalah serangkaian usaha aktif yang diterapkan oleh orang tua dalam berinteraksi dengan anakanaknya, meliputi cara mendidik, memberikan perlindungan, perhatian, aturan-aturan, hadiah atau hukuman, serta tanggapan terhadap anaknya dalam kehidupan seharihari. Nashori (2006) menyatakan dalam khazanah pemikiran psikologi kontemporer, 
gagasan tentang peran orangtua dalam meningkatkan spiritualitas termasuk konsep Tuhan pada diri anak diwadahi oleh konsep spiritual parenting. Pamugari (dalam Irianto, 2002; Levin, 2000; Nars, 1991) mendefenisikan spiritual parenting sebagai sistem pengasuhan anak dengan paradigma menanamkan keimanan dan kesadaran rohani.

Sementara menjadi orang tua dengan menerapkan spiritual parenting berarti memprioritaskan kehidupan diri kita sendiri, dimana Tuhan berada pada urutan tertinggi, sehingga jiwa orangtua dan jiwa anak menjadi sangat penting. Spiritual parenting mengimplikasikan bahwasanya orang tua tidak hanya hadir untuk anak mereka, namun juga untuk diri mereka sendiri (Hart, 2004). Seseorang yang lebih dulu mengakui diri sendiri sebagai makhluk spiritual, maka seseorang itu dapat mendidik anak-anak dengan menyadari bahwa anak-anak adalah individu yang benar-benar berketuhanan (Doe, 1998).

Hidayat (dalam Irianto, 2002) menambahkan bahwa prinsip spiritual parenting bisa diterapkan misalnya dengan mengajak anak untuk mengapresiasi Tuhan melalui ciptaannya, bisa melalui keindahan alam, sinar matahari, ataupun warnawarni bunga, anak diajak mengagumi dan menghayati karya Tuhan. Doe (dalam Irianto, 2002) lewat bukunya juga mengutarakan cara mengimplementasi prinsip spiritual parenting, inti penerapannya tidak jauh berbeda dengan pendidikan agama yang diterapkan selama ini. Bedanya, metode baru ini tidak mencekoki anak dengan doktrin-doktrin ketuhanan. la merangsang anak untuk berpikir tentang Tuhan, memberikan pencitraan Tuhan yang mencintai, bukan Tuhan yang menunggu dengan rotan untuk memukul.

Inti dari spiritual parenting adalah usaha yang dapat ditempuh orang tua dalam kehidupan sehari-hari untuk menguatkan spiritualitas anak. Gagasan umumnya adalah mengakrabkan konsep Tuhan kepada anak-anak sejak usia dini (Nashori, 2006). Berdasarkan uraian di atas maka pengertian spiritual parenting adalah pola asuh menempatkan Tuhan pada urutan tertinggi, dalam sikap dan perilaku, yang diterapkan oleh orang tua dalam berinteraksi dengan anak, meliputi cara orang tua memberikan aturan-aturan, atau hukuman, dan cara orangtua memberikan perhatian serta tanggapan terhadap anaknya. Menurut
Nashori (2006) komponen dari spiritual parenting meliputi pola asuh menempatkan Tuhan pada urutan tertinggi, dalam sikap dan perilaku, yang diterapkan oleh orang tua dalam berinteraksi dengan anak, meliputi cara orang tua memberikan aturan-aturan, atau hukuman, dan cara orangtua memberikan perhatian serta tanggapan terhadap anaknya.

\section{Metode}

\section{Desain Penelitian}

Terdapat dua variable dalam penelitian ini, yakni pengasuhan spiritual sebagai variabel bebas dan karakter yang baik sebagai variabel terikat. Partisipan dalam penelitian ini ialah mahasiswa aktif yang sedang menempuh Pendidikan S1 di Fakultas Psikologi UIN Suska Riau. Partisipan di ambil dengan menggunakan stratified random sampling, Partisipan berjumlah 200 mahasiswa. Jumlah partisipan perempuan adalah 167 orang dan jumlah partisipan laki-laki 33 orang.

\section{Pengukuran}

Alat ukur yang digunakan untuk mengukur variable Pengasuhan Spiritual adalah Skala Spiritual Parenting yang disusun penulis berdasarkan indikator menurut Nashori (2006). Untuk mengukur variable karakter yang baik menggunakan Skala Karakter yang baik yang disusun penulis berdasarkan indikator menurut Madjid (2000).Aitem pada skala ini bersifat favourable dan unfavourable. Metode yang digunakan adalah metode Likert yang terdiri dari empat alternatif jawaban, yaitu: (SS) Sangat Sesuai, (S) Sesuai, (TS) Tidak Sesuai, dan (STS) Sangat Tidak Sesuai. Sebelum alat ukur digunakan untuk penelitian terlebih dahulu dilakukan try out terhadap 100 orang. Dari hasil try out itu maka diperoleh kefisien reliabilitas sebesar 0,863 (bagus sekali) untuk skala pola asuh. Koefisien reliabilitas untuk skala karakter yang baik adalah 0,907 (bagus sekali).

Menurut teori yang digunakan dalam penelitian ini skala pengasuhan spiritual menempatkan Tuhan pada urutan tertinggi, dalam sikap dan perilaku, yang diterapkan oleh orang tua dalam berinteraksi dengan remaja, meliputi cara orang tua memberikan aturan-aturan, atau hukuman, dan cara orangtua memberikan perhatian serta tanggapan terhadap remajanya. Jumlah Aitem pada skala spiritual parenting adalah 16 aitem dengan 13 aitem favorable dan 3 
aitem unfavorabel. Dengan contoh aitem sebagai berikut: "Orang tua saya dalam mendidik anak-anaknya selalu berlandaskan nilai-nilai kelslaman".,"Saya tidak mengetahui nilai-nilai Islam karena orang tua saya tidak pernah mengajarkan tentang hal itu".,dan "Setiap bersikap dan bertingkah laku orang tua selalu mengajarkan saya untuk mengingat Allah SWT".

Sedangkan untuk skala karakter yang baik meliputi komponen pengetahuan, kesadaran atau kemauan, dan tindakan untuk melakukan nilai-nilai tersebut, baik kepada Tuhan Yang Maha Esa, diri sendiri, sesama, lingkungan, maupun kebangsaan sehingga menjadi manusia insan kamil yang meliputi moral knowing atau pengetahuan tentang moral, moral feeling atau perasaan tentang moral dan moral action atau perbuatan moral. Jumlah Aitem pada skala spiritual parenting adalah 26 aitem dengan 15 aitem favorable dan 11 aitem unfavorabel. Dengan contoh aitem sebagai berikut: "Saya mengetahui bahwa berkata kasar pada kedua orang tua dan dosen dikampus adalah perbuatan yang salah".,"Saya memiliki kesadaran untuk menjalankan tugas saya sebagai seorang mahasiswa".,dan "Walaupun menghormati orang tua itu merupakan sesuatu yang dianjurkan, tetapi bagi saya itu bukan sesuatu yang menyenangkan".

\section{Analisa Data}

Teknik analisa data yang digunakan untuk menjawab hipotesis dalam penelitian ini adalah menggunakan teknik korelasi product moment melalui program SPSS 24.00 for windows.

\section{Hasil}

Uji asumsi terdiri dari uji normalitas dan uji linearitas data untuk mengetahui apakah data penelitian berdistribusi secara normal dan linear. Pengujian normalitas dan linearitas dilakukan dengan menggunakan bantuan SPSS 18 for windows. Berdasarkan uji normalitas menggunakan One Sample Kolmogorof Smirnov Test dapat dilihat bahwa signifikansi (Asymp Sig) untuk variabel Spiritual Parenting (X1) $p=0,388(p>0,05)$, dan signifikansi untuk variabel Karakter yang Baik (Y) $p=0,492(p>0,05)$. Dengan demikian dapat disimpulkan bahwa sebaran data pada kedua variabel di atas adalah normal. Sedangkan dari hasil uji linearitas yang dilakukan diketahui bahwa nilai signifikansi $p=0,000$. Karena nilai signifikansinya lebih kecil dari 0,05 maka data dapat dikatakan linear.

Berdasarkan hasil uji hipotesis yang dilakukan untuk mengetahui seberapa besar tingkat signifikansi hubungan antara Spiritual Parenting dengan Kaarakter yang Baik pada Mahasiswa. Dari hasil analisis Korelasi Product Moment diperoleh koefisien korelasi ( $r)$ sebesar $=0,412$, dengan nilai $p=0,000$ $p \leq 0,05$. Maka dapat disimpulkan bahwa hipotesis yang diajukan diterima. Artinya semakin baik pola pengasuhan spiritual maka semakin baik karakter yang terbentuk pada diri mereka.

Tabel 1. Uji Perbedaan Berdasarkan jenis Kelamin

\begin{tabular}{cccccc}
\hline Variabel & Jenis Kelamin & Mean & $\mathbf{t}$ & $\begin{array}{c}\text { Sig } \\
\text { (2-tailed) }\end{array}$ & Keterangan \\
\hline Spiritual & Perempuan & 52.0969 & 5.673 & 0.000 & Ada Perbedaan \\
Parenting & Laki-laki & 44.3305 & & & \\
\hline $\begin{array}{c}\text { Karakter yang } \\
\text { baik }\end{array}$ & Perempuan & 51.7878 & 4.057 & 0.000 & Ada Perbedaan \\
& Laki-laki & 45.1662 & & & \\
\hline
\end{tabular}

Pada tabel 1 diketahui bahwa spiritual parenting atau pengasuhan spiritual berdasarkan jenis kelamin menunjukkan adanya perbedaan antara spiritual parenting yang diterima subjek perempuan dan subjek laki-laki dengan signifikansi sebesar 0,000 (memenuhi syarat $p<0,05$ ). Subjek perempuan mendapatkan spiritual parenting yang lebih besar dibanding subjek laki-laki (rata-rata perempuan $\mu=52,0969$; rata-rata laki-laki $\mu=44,3305$ ).

Sedangkan hasil analisis karakter yang baik berdasarkan jenis kelamin juga menunjukkan terdapat perbedaan, dimana hasil analisis perbedaan menunjukkan signifikansi sebesar 0,000 (memenuhi syarat 
p < 0,05). Karakter yang baik pada subjek perempuan lebih tinggi dibandingkan dengan karakter yang baik pada subyek laki-laki (ratarata perempuan $\mu=51,7878$; rata-rata lakilaki $\mu=45,1662)$.

\section{Pembahasan}

Hasil analisis regresi ganda pada penelitian ini menunjukkan bahwa terdapat hubungan positif yang sangat signifikan antara spiritual parenting dengan karakter yang baik pada remaja dengan nilai koefisien korelasi $(r)$ sebesar $0,412(p=0.000)$. Artinya semakin baik pola pengasuhan spiritual maka semakin baik karakter yang terbentuk pada diri mereka. Hasil penelitian ini sejalan dengan yang dikemukakan oleh Matta, 2006.,Elmubarok, 2008.,Romlah, 2008. Mereka menjelaskan bahwa faktor yang mempengaruhi terbentuknya karakter yang baik pada individu remaja adalah lingkungan keluarga, lingkungan sosial dan lingkungan pendidikan. Karakter merupakan evaluasi kualitas tahan lama suatu individu tertentu atau disposisi untuk mengekspresikan perilaku dalam pola tindakan yang konsisten diberbagai situasi. Hal ini menunjukkan bahwa karakter memang terbentuk karena pola tindakan yang berstruktur dan dilakukan berulang-ulang. Pola yang berstruktur ini diperoleh remaja salah satunya melalui pola asuh yang diterapkan oleh orang tua dan proses interaksi sosial antara remaja dengan sahabatnya. (Koesuma, 2004).

Sopidi, 2007 dan Rahmat, 2010, dalam penelitiannya tentang perkembangan sikap keagamaan lewat pengasuhan, juga menyimpulkan bahwa sikap dan karakter beragama pada remaja ditentukan oleh pola asuh orangtua yang berlandaskan nilainilai agama dalam mendidik dan mengasuh remaja. Pola berpikir, perasaan dan karakter serta prilaku remaja yang didasarkan pada nilai-nilai agama adalah bentuk aktualisasi dari pola pengasuhan yang diterapkan oleh orangtuanya.

Menurut Budiningsih (2004), Simon (2005) dan Niale (2004) karakter dapat terbentuk dipengaruhi oleh faktor internal dan eksternal. Faktor eksternal yang sangat mempengaruhi pembentukan karakter seseorang menjadi baik atau tidak baik adalah lingkungan keluarga dan lingkungan sosial. Nilai-nilai yang berkembang di dalam keluarga dan pola pengasuhan kedua orang tua terhadap remaja akan sangat mempengaruhi prilaku dalam semua tahap perkembangannya termasuk dalam pembentukan karakter mereka. (Lexmond \& Reeves, 2009; Smith \& Allen, 2008.). Pola asuh yang spiritual atau menanamkan nilai-nilai agama di dalam mendirik dan mengasuh anak akan mampu menciptakan karakter yang baik pada diri remaja.

Keberhasilan keluarga membangun karakter remaja akan bermuara pada masyarakat yang warganya memiliki karakter yang baik, dan kegagalan keluarga dalam membentuk karakter remaja akan berakibat pada tumbuhnya masyarakat yang tidak berkarakter. Oleh karena itu setiap keluarga harus memiliki kesadaran bahwa karakter bangsa sangat bergantung pada pendidikan karakter remaja dirumah (Widajat, 2011, Hartati, 2007).

Pola pengasuhan orang tua sangat mempengaruhi kehidupan dan kepribadian serta pembentukan karakter remaja. Remaja yang dididik dengan penanaman nilainilai agama, moral social dan kemanusian yang baik akan membangun karakter yang baik pula pada remaja. (Boumrind, 1991). Pola pengasuhan orang tua dengan nilai cinta dan kasih sayang akan membangun perkembangan moral yang positif dan meningkatkan kesejahteraan psikologis pada diri individu remaja. (Lexmond \& Reeves, 2009; Cowan, 2002; Feinstein \& Bynner, 2004; Gillham et al, 2006; Kiernan \& Huerta, 2008)

Pendidikan yang diberikan kepada remaja dimulai dari mereka masih anak-anak akan memiliki pengaruh yang besar bagi perkembangan jiwa mereka. Masa ini adalah masa persiapan dan pengarahan bagi remaja. Berdasarkan latar fenomena yang terjadi masa sekarang ini perlu upaya pembentukan karakter remaja salah satunya melalui pola asuh spiritual dalam keluarga. Spiritual parenting merupakan sistem pengasuhan remaja dengan paradigma menanamkan keimanan dan kesadaran rohani. Pendidikan keagamaan di sekolah saja tidak cukup untuk membangun spiritualitas remaja (Jahja, 2011; Sugiyatno, 2010; Shochib, 2000; Sjarkawi, 2006).

Pola pengasuhan remaja dalam spiritual parenting membantu menyadarkan remaja sedini mungkin bahwa mereka adalah ciptaan Tuhan dan mempunyai kewajiban untuk beribadah kepada Nya. Pola pengasuhan ini sangat mudah untuk diterapkan karena konsep spiritualitas hadir 
selalu dalam kehidupan kita sehari-hari, misalnya dalam percakapan orangtua dengan remaja, menyelesaikan tugas sehari-hari, mendongeng sebelum tidur dan sebagainya. Spiritual parenting merangsang remaja untuk berpikir tentang Tuhan sehingga remaja mampu mengendalikan diri dari pengaruh buruk lingkungan karena tidak sesuai dengan apa yang diajarkan kepada mereka. Jika remaja-remaja merasakan kehadiran Tuhan dalam setiap aspek kehidupan, mereka akan berkembang menjadi remaja yang taat beribadah. Remaja akan menyadari bahwa beribadah dalam kehidupan sama halnya beribadah dalam agama. (Hany, 2013.,Bert, 2011.,Callaghan, 2005.,Zohar \& Marshall, 2001)

Pada penelitian ini juga dilakukan analisa tambahan sehingga ditemukan bahwa terdapat perbedaan karakter antara subyek laki-laki dan perempuan. Perempuan memiliki karakter baik yang lebih tinggi dibandingkan dengan laki-laki. Banyak masyarakat menganggap kaum perempuan dianggap bersifat memelihara, rajin, lemah, lembut dan sabar. Sehingga semua pekerjaan domestik dalam kegiatan sehari-hari seperti memasak, mencuci, bebenah, mengurus anak-anak dan lainlain menjadi tanggung jawab perempuan. Sedangkan laki-laki dianggap perkasa, kuat, tidak cocok pada pekerjaan domestik. Hal ini menuntut perempuan untuk memiliki karakter yang baik, sehingga keluarga memberikan pengasuhan yang lebih tinggi pada unsur membangun karakter yang baik bagi perempuan. (Ermanovida, 2010)

Hasil analisis perbedaan spiritual parenting yang ditinjau berdasarkan jenis kelamin menunjukkan bahwa terdapat perbedaan antara pemberian spiritual parenting pada remaja laki-laki dan remaja perempuan. Spiritual parenting yang diterima remaja perempuan lebih tinggi dibandingkan dengan spiritual parenting yang diterima remaja laki-laki. Artinya, subjek perempuan dalam penelitian ini lebih banyak mendapatkan pola pengasuhan spiritual dari kedua orangtua mereka daripada subjek lakilaki. Ini sesuai dengan yang dikemukakan oleh Collet dan Lizardo (2008) bahwa wanita mendapatkan pengetahuan dan pengalaman religius lebih besar dari pada laki-laki. Temuan bahwa perempuan lebih religius dibanding laki-laki dinilai wajar karena mayoritas perempuan memiliki banyak kesempatan untuk mendapatkan pengalaman spiritual dan memiliki waktu luang yang cenderung lebih banyak dibanding laki-laki. Dengan waktu luang yang dimiliki, perempuan akan mengisinya dengan mempelajari ilmu-ilmu agama dengan membaca buku maupun mendatangi majelis-majelis ilmu. Ini sesuai dengan pendapat Zuraidah (2013) yang mengatakan bahwa kentalnya nuansa religius pada perempuan disebabkan karena mereka begitu aktif dalam kegiatan majelis taklim, kelompok pengajian dan juga kelompok kelompok yasinan.

Menurut Adhim (dalam Jahja, 2011, Hartati, 2017; Kurniawan \& Uyun, 2013; Megawani, 2013) menularkan nilai spiritual sama dengan menanamkan aspek dasar pendidikan moral pada remaja. Remaja akan lebih dahulu mengidentifikasikan dirinya dengan significant person (figur lekat remaja) yang dalam hal ini adalah orangtua. Sebagai pengasuh dan pembimbing dalam keluarga, orangtua sangat berperan meletakkan dasardasar berprilaku dan pendidikan agama bagi remaja-remajanya. Sikap, prilaku dan kebiasaan orangtua selalu dilihat, dinilai dan ditiru oleh remajanya yang kemudian semua itu secara sadar maupun tidak sadar diresapi kemudian menjadi kebiasaan pula bagi remaja. Hal tersebut karena remaja mengidentifikasikan dirinya pada orangtua sebelum mengidentifikasi orang lain (Papalia, 2008, Gregor, 2013; Fatimah, 2011).

Jadi peran orangtua dalam menjadikan diri mereka sebagai contoh panutan bagi remaja sangatlah penting. Pada masamasa awal perkembangan remaja, remaja akan menghabiskan waktu mereka dengan melakukan imitasi dan identifikasi yang pesat terhadap lingkungan terdekat remaja yaitu orangtua. Orang tua merupakan role model bagi remaja di dalam lingkungan keluarga yang pertama mereka kenal. Jika orang tua jauh dari nilai-nilai spiritualitas, maka remajapun juga akan mengikuti jejak orangtuanya. Seperti kata pepatah, buah jatuh tidak jauh dari pohonnya. Remaja yang cerdas spiritual sebagian besar dilahirkan dari orang tua yang cerdas secara spiritual, begitu juga sebaliknya. (Reinert, 2005., Tabitha, 2014; Notosrijoeno, 2016; Imanuddin,2015).

\section{Kesimpulan}

Berdasarkan hasil penelitian dan pembahasan di atas, maka dapat disimpulkan bahwa terdapat hubungan yang signifikan antara pola pengasuhan spiritual dengan karakter yang baik pada remaja. Artinya semakin baik pola pengasuhan spiritual yang 
diberikan oleh orang tua terhadap remaja maka semakin baik karakter remaja yang terbentuk. Sebaiknya orang tua mampu menerapkan pola asuh yang baik dengan mengedepankan nilai-nilai agama yang diaplikasikan dalam kehidupan remaja seharihari sehingga mempu membentuk karakter remaja yang baik dan berlandaskan nilai-nilai agama yang dianut.

\section{Daftar Pustaka}

Arismantoro. (2008). Tinjauan Berbagai Aspek Character Building. Bagaimana Mendidik Anak Berkarakter. Yogyakarta: Tiara Wacana.

Atwater, E. (1992). Adolescence. Toronto Canada Inc: Prectice-Hall.

Atkinson, AB., AK Maynard, CG Trinder 1983). Parents and Children: Incomes in two generations (London: Heinemann Educational.

Baumrind, D, (1991).'The influence of parenting style on adolescent competence and substance use', Journal of Early Adolescence 11(1), 56-95,

Bert, S.C. (2011). The influence of religiosity and spirituality on adolescent mothers and their teenage children. Journal Youth Adolescence, 40, 72-84. Doi 10.1007/ s10964-010-9506-9.

Cowan, Pand Cowan C. (2002). 'Strengthening couples to improve children's wellbeing', Poverty. Clinical Science. Barkeley California

Callaghan, D.M. (2005). The influence of spiritual growth on adolescents' initiative and responsibility for self-care. Journal Pediatric Nursing, 31(2). ProQuest Professional Education. Pages, 91-97

Collett, Jessica L., \& Lizardo, Omar. 2008). A Power-Control Theory of Gender and Religiosity. Department of Sociology: University of Notre Dame.

Diane E. Papalia, Sally W Old, Ruth D, Feldmen. (2008). Psikologi Perkembangan (terjemahan) Bagian I s/d IV. Jakarta: Kencana Media Group.

Doe, Mimi dan Warsha Walch. (2001). 10 Prinsip Spiritual parenting; Bagaimana Menumbuhkan dan Merawat Sukma
Anak-anak. Bandung: Kaifa.

Ermanovida. (2010). Memahami Pembagian Peran Gender Antara Laki.Laki Dan Perempuan Dalam Keluarga.

Feinstein, L and Bynner, J. 2004. 'The importance of cognitive development in middle childhood for adulthood socioeconomic status, mental health, and problem behavior', Child Development 75, no 5. Pages, 1329-1339

Gillham, JE Reivich, K.J.,Freres, DR.,Lascher, M \& Seligman, E.P. (2006). 'School-based prevention of depression and anxiety symptoms in early adolescence: a pilot of a parent intervention component', School Psychology Quarterly 21

Gregor, H. (2013). Theology of Parenting. Andrew University, Michigan USA. Biblijski pogledi, 21 (1-2), 115-130.

Hartati, S. (2017). Konsep spiritual Parenting dengan Pendekatan Konseling Behavioristik dalam Membentuk Moral Anak. Jurnal Bina Gogik, Vol.4 No.1. Hal. 23553774

Hurlock, E.B. (1973). Adolescent Development (4th ed). Tokyo: McGraw-Hill Kogakusha Ltd.

- (1978). Child Development. New York: Mc. Millan Publishing co.Inc.

. (1999). Psikologi Perkembangan, Suatu Pendekatan sepanjang Rentang Kehidupan. (terjemahan). Jakarta: Erlangga.

Ibda, Fatimah. (2011). Perkembangan Moral Pada Anak Dan Relevansinya Dengan Pendidikan. Jurnal IImiah Didaktika, Vol.11. No.1. Hal.380-391

Imanuddin, Aam. 2015. Mengembangakan Kesejahteraan Spiritual Peserta Didik Sebagai Katalis Bangsa Inovatif. Jurnal Pedagogik. Vol.3. No 1. Hal.51-59

Jahja, Yudrik. (2011). Psikologi Perkembangan Jakarta: Kencana Prenada Media Group.

Jalaluddin, (2010). Psikologi Agama. Jakarta: PT.Raja Grafindo Persada.

Kiernan, K and Huerta, M,. (2008). 'Economic deprivation, maternal depression, parenting and children's cognitive and emotional development in early childhood', British Journal of Sociology 
Vol.59, no 4. Pages 783-806

Kurniawan, Irwan Nuryana \& Qurotul Uyun. (2013). Penurunan Stres Pengasuhan Orang Tua Dan Disfungsi Interaksi Orang Tua-Anak Melalui Pendidikan Pengasuhan Versi Pendekatan Spiritual (Pp-Vps), Jurnal Intervensi Psikologi, Vol.5. No.1

Lexmond, J \& Reeves, R. (2009). Building Character. Mixed Source, Demos London Levin, M. (2000). Spiritual Intelligence: Awakening the Power of Your Spirituality and Instuttion. London: Hodder \& Stoughton

Lickona, T., Schaps, \& Lewis (2003). Eleven Principle of Effective Character Education. The Fourth and Fifth RS, Vol.10. Cortland: School of Education.

Magawani, Ratna. (2007). Character Parenting Space, cet. I. Bandung: Read! Publishing House

Matta, A. (2006). Membentuk Karakter Anak. Penerbit Fitrah Rabbani. Jakarta.

Megawangi, R. (2003). Pendidikan Karakter untuk Membangun Masyarakat Madani. IPPK Indonesia Heritage Foundation.

Mujib, (2012). "Konsep Pendidikan Karakter Berbasis Psikologi Islam " Prosiding Seminar Nasional Psikologi Islami.

Musfiroh, Tadkiroatun.(2008). Pengembangan Karakter Remaja Melalui Pendidikan Karakter.

Tinjauan Berbagai Aspek Character Buiding. Yogyakarta : Penerbit Tiara Wacana.

Madjid, N. (2000). Masyarakat Religius: Membumikan Nilai-Nilai Islam dalam Kehidupan Masyarakat. Jakarta: Paramadina.

Monks, F.J,K \& Haditono, S..R. (1999). Psikologi Perkembangan. Yogyakarta: Gadjah Mada University Press.

Marsha Walch, Mimi Doe. (2001). 10 Prinsip Spiritual Parenting. Bandung: Mizan.

Nasr, Sayyed Hossein. (1991). Islamic Spirituality. New York: Crossroad

Nana Syaodih Sukmadinata. (2005). Landasan Psikologi Proses Pendidikan, cet-3. Bandung.Remaja Rosdakarya

Neale, B (ed), (2004). Young Children's Citizenship: Ideas into practice (York:
Joseph Rowntree Foundation

Notosrijoedono, R. A. Anggraeni. (Tanpa tahun.) Menanamkan Kecerdasan Moral Sejak Anak Usia Dini pada Keluarga muslim. (diunduh dari google schoolar), 10 Juni 2016.

Nuryoto, S. (1992). Kemandirian Remaja ditinjau dari Tahap Perkembangan, dan Peran Jenis Kelamin. Disertasi. (tidak diterbitkan). Yogyakarta: Fakultas Psikologi Universitas Gadjah Mada.

Papalia, D.F. and Olds, S.W. (2005). Human Development. 6th ed. Boston: McGrawHill Companies, Inc.

Petro, M.R, Rich, E.G.,Erasmus, C., and Roman, N.V (2017). The effect of Religion on Parenting in order to Guide Parents in the Way They Parent. Journal of Spirituality in Mental Health. ISSN: 1934-9637

Q-Anees Bambang, Adang Hambali. 2008). Pendidikan Karakter Berbasis Al Quran. Bandung: Simbiosa Rekatama Media, Rahmat, (2010). Keluarga dan Pola Asuh Remaja. Jurnal Studi Gender \& Remaja. 5(1) 35-46

Reinert, D.F. (2005). Self-representations, and attachment to parents: A Longitudinal Study of Roman Catholic College Seminarians. Journal Spirituality Counseling and Value, ProQuest Professional Education Vol. 49, Issue 3. pages. 226-238.

Romlah, T. (2008). Pembentukan dan Pembinaan Karakter. Malang

Santrock, J.W. (2008). Educational Psychology (3th ed). Boston:Mc.Graw Hill Santrock, J.W. (1999). Life Span Development. (terjemahan). Boston: Mac Graw-Hill.

(1996). Adolescence. Perkembangan Remaja. (terjemahan). Jakarta:Erlangga.

Sarwono, S.W. (2002). Psikologi Remaja. Edisi Enam. Jakarta: Raja Grafindo Persada.

Simons, R. (2005). 'Collective efficacy, authoritative parenting and delinquency: a longitudinal test of a model of integrating community and family level processes', Criminology Journal. Vol.43, Issue 4. 
Pages, 989-1029.

Smith, ID and Allen, G. (2008). Early Intervention: Good parents, great kids, better citizens (London: Centre for Social Justice and the Smith Institute

Sopidi, (2007). Perkembangan Sikap Keagamaan: Agama dan Pengasuhan. Jurnal Al-Tarbiyah edisi XX, Vol 1 Juni 2007. Stain Cirebon.

Sudrajat, A. (2010).Tentang Pendidikan Karakter. Penerbit Kencana Prenada Media Grup. Jakarta

Sugiyatno. (2010). Optimalisasi Peran Keluarga dalam Membangun Moral Anak. Jurnal Dinamika Pendidikan. [1] XVII, Mei.

Shochib, Moh. (2000). Pola Asuh orang Tua dalam Membantu Anak Mengemangkan Disiplin Diri. Jakarta: Rineka Cipta.

Sjarkawi. (2006). Pembentukan Kepribadian Anak; Peran Moral, Intelektual, Emosional, dan Sosial sebagai Wujud Integritas Membangun Jati Diri. Jakarta: PT. Bumi Aksara.

Tabitha, N. (2014). A Study of the link between self-esteem and spiritual experience of parents living in the 'City of Sadness' of Hong Kong.Journal of the North American Association of Christians in Social Work. Social Work \& Christianity, 41(1), 45-59.

Ledwell, M. King, V. (2013). Religion and Ties Between Adult Children and Their Parent. The journal of Gerontology. Vol 68, Issue 5, Sept 2013 pages 825-836.

Widajat, Wahyu. (2011). Buletin Pendidikan Karakter. Surabaya

Zohar, D. \& Marshall, I. (2001). SQ kecerdasan spiritual. Bandung, ID: Mizan

Zuraidah. (2013). Peran Perempuan dalam Membangun Masyarakat Religius di Kabupaten Indragiri Hilir. Sosial Budaya.10(1). 38-46. 